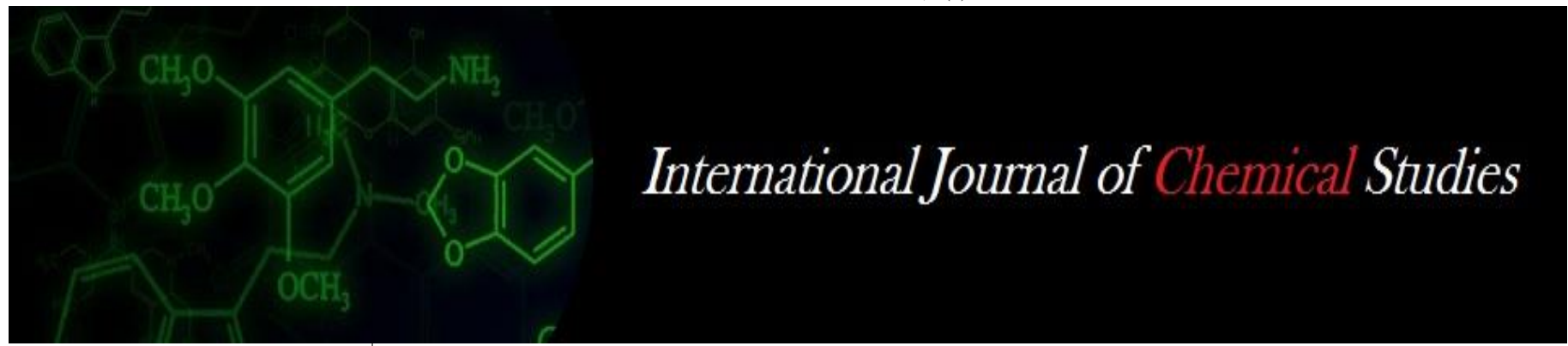

P-ISSN: 2349-8528

E-ISSN: 2321-4902

www.chemijournal.com

IJCS 2020; 8(2): 566-568

(C) 2020 IJCS

Received: 01-01-2020

Accepted: 03-02-2020

\section{Baranidharan R}

Department of Floriculture and

Landscape Architecture, HC \&

RI, TNAU, Coimbatore,

Tamil Nadu, India

\section{P Aruna}

Department of Floriculture and Landscape Architecture, $\mathrm{HC} \&$ RI, TNAU, Coimbatore,

Tamil Nadu, India

\section{SP Thamaraiselvi}

Department of Floriculture and Landscape Architecture, $\mathrm{HC} \&$ RI, TNAU, Coimbatore,

Tamil Nadu, India

\section{S Srinivasan}

Department of Floriculture and Landscape Architecture, HC \& RI, TNAU, Coimbatore,

Tamil Nadu, India

Mangaiyarkarasi R Department of Floriculture and Landscape Architecture, HC \& RI, TNAU, Coimbatore,

Tamil Nadu, India
Corresponding Author: Baranidharan R

Department of Floriculture and Landscape Architecture, HC \& RI, TNAU, Coimbatore, Tamil Nadu, India

\section{Study on effect of different growth hormones on growth, yield and quality of African marigold (Tagetes erecta $\mathrm{L}$ )}

\author{
Baranidharan R, P Aruna, SP Thamaraiselvi, S Srinivasan and \\ Mangaiyarkarasi $\mathbf{R}$
}

DOI: https://doi.org/10.22271/chemi.2020.v8.i2i.8824

\begin{abstract}
This investigations were undertaken to study the effect different growth hormones on growth and yield of African marigold (Tagetes erecta L.) under Coimbatore condition, during March 2019 to October 2019 in two different seasons. The present experiment was laid out in randomized block design with three replications involving foliar application of Gibberellic acid, Cycocel, Brassinosteroids, and silicic acid. The study revealed that foliar application of Gibberellic acid $\left(\mathrm{T}_{2}\right)$ at the rate of 150ppm showed a significant improvement in morphology and yield and quality parameters in African marigold. The result recorded of maximum plant height $(72.52 \mathrm{~cm})$, plant spread $(40.89 \mathrm{~cm})$, number of primary branches (9.77), number of flowers per plant (36.52), single flower weight $(6.56 \mathrm{~g})$, flower diameter $(6.40 \mathrm{~cm})$, flower yield per plant $(239.57 \mathrm{~g})$ and highest total carotenoid content $(1.32 \mathrm{mg} / \mathrm{g})$ and total xanthophyll content $(1.71 \mathrm{mg} / \mathrm{g})$ and total chlorophyll content $(2.60 \mathrm{mg} / \mathrm{g})$ were recorded in the treatment $\mathrm{T}_{2}$. whereas the Cycocel (CCC) at the rate of 2000ppm recorded dry matter production (62.93 g per plant), days taken for flower bud appearance (32.61 days), days to first harvest (51.53 days) as compared to control.
\end{abstract}

Keywords: African marigold, $\mathrm{GA}_{3}$, cycocel, growth, yield

\section{Introduction}

Marigold is a genus of Tagetes, widely used as annual, perennial and herbaceous plant belongs to the family of asteraceae. The flower is known as 'flower of the dead' in Mexico and the name was described by Carl Linnaeus in 1753. It has gained popularity in India on account of its easy cultivation, wider adaptability and production throughout the year. Moreover, Commercial extraction of carotenoid pigments also plays a major role. It has been extracted from $T$. erecta, $T$. patula and $T$. grandiflora and $T$. nana. $\mathrm{GA}_{3}, \mathrm{CCC}$ of preceding PGRs including new up-coming PGRs like BRs and elemental nutrients like Si application improves the growth and yield potentials of agronomics and horticultural crops, the treasury of research has been extended to marigold to obtain enhanced yield and improved flower quality. Gibberellic acid $\left(\mathrm{GA}_{3}\right)$ has been found to be effective in enhancing plant growth and marigold flower development (Girwani et al., 1990) ${ }^{[12]}$. Promoting the initiation of floral primordium by antagonizing the inhibitory effect on floral initiation of endogenous abscissic acid levels. Exogenous foliar application of growth regulators is also observed to promote flowering, pollination, fertilization and seed setting to achieve maximum seed yield (Doddagoudar et al., 2002) ${ }^{[11]}$

\section{Materials and Methods}

The experiment was conducted in in Kharif i.e., summer (March-June) and rainy (JulyOctober) seasons at the Coimbatore District under the Department of Floriculture and Landscape Architecture, Tamil Nadu Agricultural University, Coimbatore in the year 20182019. The design of experiment is Randomized Block Design. The various plant growth hormones like Gibberellic acid $\left(\mathrm{GA}_{3}\right)$, Brassinosteroids (BRs), Cycocel (CCC) and supplemented mineral nutrient silicic acid $(\mathrm{Si})$ were given as foliar spray. They were sprayed in two different intervals of 10 days and 15 days after transplanting from 30 days continued until 45 days. Observed all plant morphological, yield and quality parameters. 
The treatments used were T1: Foliar spray of GA 3 @100ppm @10 days interval, T2: Foliar spray of $\mathrm{GA}_{3} @ 150 \mathrm{ppm} @ 15$ days interval, T3: Foliar spray of BRs @0.50ppm @10 days interval,T4: Foliar spray of BRs @0.75ppm @15 days interval,T5: Foliar spray of silicic acid@6 ml/1@10 days interval,T6: Foliar spray of silicic acid@8ml/1@15 days interval,T7: Foliar spray of CCC @1500ppm @10 days interval,T8: Foliar spray of CCC @2000ppm @15 days interval,T9: Control (water spray)

\section{Results and Discussion \\ Growth parameters}

Among the treatments $T_{2}$ (Gibberellic acid at the rate of $150 \mathrm{ppm}$ at 15 days interval) influenced the plant height, plant spread and number of primary branches significantly.
Increases in growth due to the increase in levels of exogenous gibberellins which are responsible for cell elongation. Table 1 results revealed that the treatment $\mathrm{T}_{2}\left(\mathrm{GA}_{3} @ 150 \mathrm{ppm}\right)$ recorded maximum plant height $(72.52 \mathrm{~cm})$, plant spread $(40.89 \mathrm{~cm})$, number of primary branches $(9.77)$ compared to all other treatments. Similar result were observed the treatment $\mathrm{GA}_{3} 150 \mathrm{ppm}$ recorded better results for marigold cv. Siracole. Swathi Imandi et al., (2017) ${ }^{[1]}$

Similar results were also obtained in African marigold cv. Pusa Narangi Gainda, where $\mathrm{GA}_{3}$ at the rate of $150 \mathrm{ppm}$ with soil application of Azotobacter resulted in increased the maximum plant height, number of primary and secondary branches per plant, plant spread, compared to the control. Naresh Kumar et al., (2016) ${ }^{[2]}$ and Sharma et al., (2016) ${ }^{[3]}$ reported in African marigold $\left(\mathrm{GA}_{3} @ 300 \mathrm{ppm}\right)$

Table 1: Effect of growth hormones on morphological parameters of African marigold

\begin{tabular}{|c|c|c|c|c|c|c|c|c|c|}
\hline \multirow{2}{*}{ Treatments } & \multicolumn{3}{|c|}{ Plant height $(\mathbf{c m})$ at DAT } & \multicolumn{3}{c|}{ Plant spread (cm) at DAT } & \multicolumn{3}{c|}{ Number of primary branches DAT } \\
\cline { 2 - 10 } & $\mathbf{3 0}$ & $\mathbf{4 5}$ & $\mathbf{6 0}$ & $\mathbf{3 0}$ & $\mathbf{4 5}$ & $\mathbf{6 0}$ & $\mathbf{3 0}$ & $\mathbf{4 5}$ & $\mathbf{6 0}$ \\
\hline $\mathrm{T} 1$ & 40.52 & 57.53 & 68.13 & 18.92 & 24.85 & 39.06 & 5.81 & 8.16 & 8.99 \\
\hline $\mathrm{T} 2$ & 43.33 & 65.06 & 72.52 & 18.81 & 24.72 & 40.89 & 6.02 & 8.64 & 9.77 \\
\hline $\mathrm{T} 3$ & 30.55 & 51.11 & 61.11 & 20.77 & 26.21 & 35.17 & 4.92 & 7.42 & 8.56 \\
\hline $\mathrm{T} 4$ & 29.25 & 50.69 & 65.55 & 19.93 & 24.37 & 38.89 & 5.86 & 7.87 & 8.82 \\
\hline $\mathrm{T} 5$ & 28.24 & 48.11 & 65.20 & 17.70 & 23.78 & 36.27 & 5.01 & 7.90 & 8.92 \\
\hline T6 & 22.82 & 42.46 & 64.90 & 16.77 & 21.82 & 35.39 & 4.63 & 6.22 & 8.38 \\
\hline T7 & 25.87 & 44.39 & 48.64 & 17.35 & 22.40 & 30.90 & 4.22 & 6.13 & 7.36 \\
\hline T8 & 28.15 & 48.92 & 49.71 & 20.45 & 24.52 & 28.55 & 4.51 & 6.46 & 7.83 \\
\hline T9 & 23.82 & 43.01 & 54.43 & 15.66 & 21.61 & 30.06 & 3.92 & 5.89 & 6.76 \\
\hline Mean & 30.28 & 50.14 & 61.13 & 18.48 & 23.81 & 35.02 & 4.99 & 7.19 & 8.38 \\
\hline SEd & 0.623 & 0.713 & 1.284 & 0.429 & 0.426 & 0.646 & 0.1173 & 0.1573 & 0.1702 \\
\hline $\mathrm{CD}(\mathrm{p}=0.05)$ & 1.322 & 1.513 & 2.723 & 0.911 & 0.904 & 1.369 & 0.2486 & 0.3335 & 0.3609 \\
\hline
\end{tabular}

$\mathrm{T}_{1}$ : Foliar spray of GA3 @ 100ppm @10 days interval, $\mathrm{T}_{2}$ : Foliar spray of GA3 @150ppm @15 days interval, $\mathrm{T}_{3}$ : Foliar spray of BRs@0.50ppm @10 days interval,T $\mathrm{T}_{4}$ : Foliar spray of BRs @0.75ppm @15 days interval, T5: Foliar spray of silicic acid@6 ml/1@10 days interval, T6: Foliar spray of silicic acid @8ml/1 @15 days interval, T 7 : Foliar spray of CCC@1500ppm @10 days interval, T8: Foliar spray of CCC @2000ppm @15 days interval,T $_{9}$ Control (water spray)

\section{Yield and quality parameters}

Flower yield parameters recorded number of flowers per plant (36.52), single flower weight $(6.56 \mathrm{~g})$, flower diameter $(6.40 \mathrm{~cm})$ and flower yield per plant $(239.57 \mathrm{~g})$ in foliar application of $\mathrm{GA}_{3} @ 150 \mathrm{ppm}\left(\mathrm{T}_{2}\right)$ showed in table 2. Similar result were noted by C.T. Sathappan (2018) ${ }^{[5]} \mathrm{GA}_{3} @ 150 \mathrm{ppm}$ in African marigold F1 hybrid viz., Gold Benz and Maxima yellow and Ramesh Kumar et al., (2010) [4] in African marigold cv. Pusa Narangi Gainda foliar application of $\left(\mathrm{GA}_{3}\right.$ @ 200ppm) and Mithilesh Kumar et al., (2014) ${ }^{[8]}$. As regard the treatment $\mathrm{T}_{8}$ (CCC @2000ppm) recorded dry matter production (62.93 g per plant), days taken for flower bud appearance (32.61 days), days to first harvest (51.53 days). Similar findings were noticed by YR Khobragade et al., (2019) [9] and Queenie Syngkrem et al., (2018) ${ }^{[5]}$ observed in white marigold (Tagetes erecta L.) Cv. Vanilla. (Table 3.)

Table 2: Effect of growth hormones on flower yield and quality of African marigold

\begin{tabular}{|c|c|c|c|c|c|}
\hline Treatments & \begin{tabular}{|c|}
$\begin{array}{c}\text { Number of } \\
\text { flowers per plant } \\
\text { (No.) }\end{array}$ \\
\end{tabular} & $\begin{array}{l}\text { Flower yield } \\
\text { per plant }(\mathrm{g})\end{array}$ & $\begin{array}{c}\text { Total Chlorophyll content } \\
(\mathrm{mg} / \mathrm{g})\end{array}$ & $\begin{array}{l}\text { Total Carotenoid } \\
\text { content }(\mathrm{mg} / \mathrm{g})\end{array}$ & $\begin{array}{c}\text { Total Xanthophyll content } \\
(\mathrm{mg} / \mathrm{g})\end{array}$ \\
\hline $\mathrm{T} 1$ & \begin{tabular}{|l|}
35.70 \\
\end{tabular} & 226.16 & 2.38 & 1.23 & 1.55 \\
\hline $\mathrm{T} 2$ & 36.52 & 239.57 & 2.60 & 1.32 & 1.71 \\
\hline T3 & 29.15 & 148.67 & 1.91 & 1.04 & 1.28 \\
\hline $\mathrm{T} 4$ & 30.20 & 151.00 & 2.06 & 1.13 & 1.38 \\
\hline T5 & 34.94 & 180.64 & 1.92 & 1.06 & 1.23 \\
\hline T6 & 33.49 & 190.73 & 2.13 & 1.15 & 1.42 \\
\hline $\mathrm{T} 7$ & 35.03 & 211.76 & 1.65 & 0.89 & 1.04 \\
\hline T8 & 35.57 & 209.33 & 1.78 & 0.96 & 1.18 \\
\hline T9 & 27.32 & 118.30 & 1.60 & 0.81 & 1.00 \\
\hline Mean & 33.10 & 186.24 & 2.00 & 1.07 & 1.31 \\
\hline SEd & 0.554 & 4.1718 & 0.0504 & 0.0196 & 0.0262 \\
\hline $\mathrm{CD}(\mathrm{p}=0.05)$ & 1.175 & 8.8440 & 0.1068 & 0.0415 & 0.0556 \\
\hline
\end{tabular}


$\mathrm{T}_{1}$ : Foliar spray of GA3 @100ppm @10 days interval, $\mathrm{T}_{2}$ : Foliar spray of GA3@150ppm @15 days interval,T3: Foliar spray of BRs@0.50ppm @10 days interval,T 4 : Foliar spray of BRs @0.75ppm @15 days interval,T5: Foliar spray of silicic acid@6 ml/1@10 days interval,T6: Foliar spray of silicic acid@8ml/1@15 days interval, T7: Foliar spray of CCC @1500ppm @10 days interval,T: Foliar spray of CCC @ 2000ppm @ 15 days interval, $\mathrm{T}_{9}$ : Control (water spray)

Table 3: Effect of growth hormones on flower yield and quality of African marigold

\begin{tabular}{|c|c|c|c|c|c|}
\hline Treatments & $\begin{array}{c}\text { Days taken for flower bud } \\
\text { appearance (days) }\end{array}$ & $\begin{array}{c}\begin{array}{c}\text { Days to first harvest } \\
\text { (days) }\end{array} \\
\end{array}$ & $\begin{array}{c}\text { Dry matter production } \\
\text { (g/plant) }\end{array}$ & $\begin{array}{c}\text { Flower diameter } \\
(\mathrm{cm})\end{array}$ & $\begin{array}{c}\text { Single flower } \\
\text { weight }(\mathrm{g})\end{array}$ \\
\hline $\mathrm{T}_{1}$ & 37.66 & 58.32 & 48.10 & 6.22 & 6.34 \\
\hline $\mathrm{T}_{2}$ & 37.39 & 54.98 & 50.56 & 6.40 & 6.56 \\
\hline $\mathrm{T}_{3}$ & 37.06 & 57.74 & 53.83 & 5.60 & 5.10 \\
\hline $\mathrm{T}_{4}$ & 38.61 & 57.97 & 55.32 & 5.61 & 5.00 \\
\hline $\mathrm{T}_{5}$ & 35.50 & 59.56 & 56.61 & 5.28 & 5.17 \\
\hline $\mathrm{T}_{6}$ & 36.16 & 55.30 & 56.75 & 5.49 & 5.70 \\
\hline $\mathrm{T}_{7}$ & 33.93 & 53.83 & 57.89 & 5.74 & 6.05 \\
\hline $\mathrm{T}_{8}$ & 32.61 & 51.53 & 62.93 & 5.35 & 5.89 \\
\hline $\mathrm{T}_{9}$ & 41.61 & 63.89 & 46.32 & 5.06 & 4.33 \\
\hline Grand Mean & 36.72 & 57.01 & 54.25 & 5.64 & 5.57 \\
\hline SEd & 0.741 & 1.601 & 0.9202 & 0.1013 & 0.1133 \\
\hline $\mathrm{CD}(\mathrm{p}=0.05)$ & 1.572 & 3.395 & 1.9507 & 0.2147 & 0.2401 \\
\hline
\end{tabular}

$\mathrm{T}_{1}$ : Foliar spray of GA3 @ 100ppm @10 days interval, $\mathrm{T}_{2}$ : Foliar spray of GA3@150ppm @15 days interval,T3: Foliar spray of BRs@0.50ppm @10 days interval,T 4 : Foliar spray of BRs@0.75ppm @15 days interval, $\mathrm{T}_{5}$ : Foliar spray of silicic acid@6 ml/1@10 days interval,T6: Foliar spray of silicic acid@8ml/1@15 days interval, $\mathrm{T}_{7}$ : Foliar spray of CCC @1500ppm @10 days interval, Ts: Foliar spray of CCC @ 2000ppm @ 15 days interval,T : $_{9}$ Control (water spray)

\section{Quality Parameters}

The highest total carotenoid content $(1.32 \mathrm{mg} / \mathrm{g})$ and total xanthophyll content $(1.71 \mathrm{mg} / \mathrm{g})$ and total chlorophyll content $(2.60 \mathrm{mg} / \mathrm{g}$ ) were recorded in the treatment $\mathrm{T} 2$ (foliar application of GA3 at the rate of $150 \mathrm{ppm}$ at 15 days interval) Gibberellic acid is responsible for the favourable changes which influenced the quality (Table 2). These results are in accordance with the findings of Gibberellic acid at $150 \mathrm{ppm}$ was recorded growth, flower yield and quality of African marigold by Dweepjyoti Sarkar et al., (2018) [6] and chrysanthemum cv. Yellow Gold Raveendra Choudhari et al., $(2018)^{[7]}$

\section{Conclusion}

It is concluded that $\mathrm{GA}_{3} @ 150 \mathrm{ppm}\left(\mathrm{T}_{2}\right)$ for foliar application at 15 days interval is found to be the growth hormone could be used to improve the productivity and xanthophyll content of African marigold.

\section{References}

1. Swathi Imandi, Subba Reddy GV. Studies on the effect of plant growth regulators on vegetative growth, flowering, yield and shelf life of the marigold cv. Siracole. International Journal of Agricultural Science and Research (IJASR) ISSN (P): 2250-0057; ISSN (E): 2321-0087. 2017; 7:65-70.

2. Naresh Kumar, Jitendra Kumar, J.P. Singh, Himanshu Kaushik and R.K. Singh. Effect of GA3 and Azotobacter on growth and flowering in African marigold (Tagetes erecta L.) cv. Pusa Narangi Gainda. The Asian Journal of Horticulture. 2016; 11:382-386.

3. Sharma RK, Pandey RK, Nomita Laishram, Arvinder Singh. Effect of pinching and plant growth regulators on flower regulation in African marigold (Tagetes erecta L.). Journal of Ornamental Horticulture. 2016; 19(3\&4):80-86.
4. Ramesh Kumar, Mohan Ram and G.S. Gaur. Effect of GA3 and Ethrel on growth and flowering of African marigold cv. Pusa Narangi Gainda. Indian Journal of Hort. 2010; 67:362-366.

5. Sathappan CT. Effect of plant growth regulators and pinching on growth and flower yield of African marigold (Tagetes erecta L.). J Hortl. Sci. 2018; 13(1):42-47.

6. Dweepjyoti Sarkar BK, Saud P, Mahanta P, Kalita B, Neog, Madhumita C, Talukdar. Response of Pinching and Gibberellic Acid on Growth and Physiological Characteristics of African marigold. International Journal of Current Microbiology and Applied Sciences. ISSN: 2319-7706, 2018, 7.

7. Raveendra Choudhari BS, Kulkarni, Mukund Shiragur. Growth, flowering and quality of cut chrysanthemum (Dendranthema grandiflora Tzevelev.) cv. Yellow Gold, as influenced by different growth regulators. International Journal of Chemical Studies. 2018; 6(1):1458-1460.

8. Mithilesh Kumar AK, Singh, Ashok Kumar. Effect of plant growth regulators on flowering and Yield attributes of African marigold (Tagetes erecta L.) CV. Pusa Narangi Gainda. Plant Archives. 2014; 14(1):363-365 ISSN 09725210.

9. Khobragade YR, Panchbhai DM, Badole WP, Gajbhiye RP, Bhute PN. Performance of African marigold varieties to cycocel for growth and yield attributes in rainy season. International Journal of Chemical Studies. 2019; 7(2):196201.

10. Queenie Syngkrem, Vijay Bahadur VM, Prasad, Devi Singh. Effect of plant growth regulators on growth, yield and quality of flowers in white marigold (Tagetes erecta L.) Cv. Vanilla. The Allahabad Farmer, 2018, LXXIV(1).

11. Doddagoudar SR, Vyakaranahal BS, Shekhargouda M. Nalini PAS, Patil VS. Effect of mother plant and nutrition and chemical spray on growth and seed yield of China aster cv. 'Kamini'. Seed Research. 2002; 30(2):269-274.

12. Girwani A, Babu RS, Chandrasehkhar R. Response of marigold (Tagetes erecta) to growth regulators and zinc. Indian Journal of Agricultural Science. 1990; 60(3):220222. 